\title{
Canada can afford universal pharmacare - no more excuses
}

\author{
Matthew B. Stanbrook MD PhD
}

See also page 491 and www.cmaj.ca/lookup/doi/10.1503/cmaj.141564

$\mathrm{C}$ anadians embrace universal public health care as a core national value. We are proud to say that we live in a country that ensures access to health care for all, regardless of means — the problem is, that statement isn't true. A gaping hole in our supposedly universal system is the lack of public coverage for prescription drugs for most Canadians. Many Canadians face drug costs they can't afford, forcing them to either take their medicines less often than prescribed or do without them entirely, with predictable adverse health consequences. ${ }^{1}$

Universal pharmacare has been recommended by virtually every national study and Royal Commission from the time medicare was first introduced in Canada to the 2002 Romanow Report, yet we still don't have it. Governments past and present have defended their inaction on this issue by arguing that pharmacare would cost too much. Although it's not clear that there was ever good reason to assume that would be true, providing scientific evidence to refute such a claim requires a study with access to comprehensive data about the sources and magnitude of drug costs, prescribing patterns and the effects of introducing universal drug coverage from the experience of other national and international jurisdictions.

In their recent CMAJ article, Morgan and colleagues present just such a study. ${ }^{2}$ Using recently available national data on drug use and costs, they report an economic model that estimates the cost of implementing national public drug coverage. The model anticipates several key evidence-based consequences of universal pharmacare. Patients who were previously unable to access drugs would now receive them, which would drive up costs. However, the greatly enhanced purchasing power of a single national third-party payer would be expected to confer an ability to negotiate substantial reductions in the prices of many drugs, as other countries have experienced and as Canadian provinces are already trying to achieve through collaboration. The model also assumes that patients would incur modest copayments, as is the case in other countries with universal pharmacare.

The bottom line? The best estimate would require the federal government to spend an extra $\$ 1$ billion per year. That's a lot of money, but considering that federal transfers for health care to the provinces and territories amount to $\$ 35$ billion - not to mention everything the federal government spends directly on health relatively speaking, it's not that much of an increase. As with all modelling studies, these estimates rely on assumptions, and the associated uncertainties mean that costs could be higher - as much as $\$ 5.4$ billion per year in the worst imaginable case.
Equally, though, national pharmacare could well result in net savings for government - perhaps as much as $\$ 2.9$ billion per year.

Even more striking are the potential benefits to the private sector: no matter what, it would save a lot of money from pharmacare. Currently, nearly half of all drug expenditures in Canada are incurred by the private sector, divided almost evenly between individuals, whose costs would drop by more than half under pharmacare, and private drug plans, whose current costs for nearly all prescription drugs would disappear completely. Of note, a big chunk of public savings would arise from what governments presently spend on private drug coverage, such as for civil servants. With projected savings like these, one would expect that private companies, governments and individuals alike should be clamouring for pharmacare.

A small number of drug classes are key drivers of overall costs and would continue to be so with or without pharmacare. Some (e.g., biologic agents) represent classes in which many emerging new therapies are expected to arise. Thus, the $\$ 1$ billion estimate might not be stable going forward. But knowing this information may now enable policy-makers to develop specific interventions focused on reducing the impact of these key cost drivers even further.

Although the Canada Health Act has long enshrined the value of equitable, public health care coverage for all Canadians, its enactment by governments to date has been hypocritical in the absence of pharmacare. Canada has the dubious distinction of being the only country with universal health care coverage, but not universal pharmacare. As we have said before ${ }^{3}$ the time to end this hypocrisy is long overdue; all of our peer nations have already done so. The moral case for universal pharmacare has always been apparent. With a strong economic case for pharmacare also evident, there can be no more excuses for delay. In this election year, it is especially timely for Canadians to demand that their next government enact national pharmacare.

\section{References}

1. Tang KL, Ghali WA, Manns BJ. Addressing cost-related barriers to prescription drug use in Canada. CMAJ 2014;186:276-80

2. Morgan SG, Law M, Daw JR, et al. Estimated cost of universal public coverage of prescription drugs in Canada. CMAJ 2015;187:491-7.

3. Stanbrook MB, Hébert PC, Coutts J, et al. Can Canada get on with national pharmacare already? CMAJ 2011;183:E1275.

Competing interests: See www.cmaj.ca/site/misc/cmaj_staff.xhtml

Affiliation: Deputy Editor, CMAJ

Correspondence to: $C M A J$ editor, pubs@cmaj.ca

CMAJ 2015. DOI:10.1503/cmaj.150281 